\title{
SOME PROBLEMS IN THE FORMULA OF THE INTER-ETHNIC COMMUNICATION INTENSITY COEFFICIENT IN THE CONTEXT OF MODERN RUSSIAN SOCIETY
}

\author{
Mustafa B. Mustafaev, Zarema S. Mustafaeva
}

\author{
Dagestan state pedagogical university. \\ Makhachkala, Republic of Dagestan, Russian Federation \\ science-almanac@mail.ru
}

It is considered the problem of finding the formula of the inter-ethnic communication intensity coefficient in the context of the Russian modern polynational society. It should be emphasized that this concept of the theory of inter-ethnic communication is still sufficiently relevant and it was represented for the first time to the scientific community in the 1980s, by the well-known authority of Soviet Science, Professor M.S. Dzhunusov. In the view of the philosophical-anthropological and interdisciplinary approaches, as well as the migration processes both within and outside the Republic, it is justified the relevance of the studied problem, that is the problem of finding the formula of the inter-ethnic communication intensity coefficient. The concept is not only relevant, but also original. Special attention is paid to the comprehensive and interdisciplinary analysis of the concept "the formula of the inter-ethnic communication intensity coefficient" in a particularly specific region of modern Russia, such as the Republic of Dagestan, where a great number of Russian nationalities and the Republic have been sufficiently interacting for centuries. Based on regional aspect and transformation, the problem aims at the prospects of creating an integrated (variative) theoretical concept, taking into account the nature, specific characteristics and prospects of its development at a time of radical breaking of "Soviet stereotypes", traditions, analysis and evaluation of the system of national and international values and the principles of the study. Therefore, definite aspects of this reserach are objectively debatable. It covers various aspects of the problem, such as international communication (philosophicalanthropological, socio-psychological, socio-cultural, social, inculturation, identification, social contacts and relations in the system of communication and social relations).

Key words: communication, national and international communication, intensity of communication, the formula of the inter-ethnic communication intensity coefficient, objective and subjective factors for activating interpersonal and international communication.

[Мустафаев М.Б., Мустафаева 3.С. Некоторые проблемы формулы коэффицциента интенсивности межнационального общения в условиях современного российского общества]

Рассматривается проблема интенсивности межнационального общения в условиях современного полинационального российского общества. В основу положена концепция теории межнационального общения, впервые представленная научной общественности еще в 1980-е гг. известным авторитетом советской науки, профессором М.С. Джунусовым и до сих пор признается достаточно актуальной. С позиций философско-антропологического и междисциплинарного подходов, а также исследования миграционных процессов как внутри республики Дагестан, так и за ее пределами, обоснована актуальность данной теории.Основное содержание статьи посвящено всестороннему и междисциплинарному анализу концепции «формулы коэффициента интенсивности межнационального общения» в таком особо специфическом поликультурном регионе современной России как республика Дагестан, где веками проживает, взаимодействует и общается большое количество национальностей. На основе регионального преломления и трансформации данная проблема рассматривается с позиции создания целостной (вариативной) теоретической концепции с учетом характера, специфических особенностей и перспектив ее развития в момент коренной ломки "советских стереотипов», традиций, анализа и оценки системы национально-межнациональных ценностей и принципов их исследования. Поэтому отдельные положения данной статьи объективно носят дискуссионный характер. Охватываются различные аспекты проблемы межнационального общения: фрилософскоантропологические, социально-психологические, социально-культурные, проблемы социализации, 
инкультурации, идентификации, социальных связей и отношений в системе общественных отношений.

Ключевые слова: общение, внутринациональное и межнациональное общение, интенсивность общения, формула коэффрициента интенсивности межнационального общения.

Mustafa B. Mustafaev - Ph.D. of pedagogy, professor. Dagestan state pedagogical university. Makhachkala, Russian Federation.

Zarema S. Mustafaeva - candidate of philosophy, associate professor. Dagestan state pedagogical university. Makhachkala, Russian Federation.

МустафаевМустафраБайматович - докторпедагогическихнаук, профессор. Дагестанский государственный педагогический университет. е. Махачкала, Россия.

МустафраеваЗарема Сиражудиновна- кандидат философских наук, доцент. Дагестанскийгосударственныйпедагогическийуниверситет. г. Махачкала, Россия.

The problem of inter-ethnic communication is an area of interdisciplinary scientific knowledge intended to study the extremely complex, specific and multifaceted process of joint life activity among people of different nationalities in a multi-ethnic, multicultural and multi-religious society. In fact, it is a question of finding a new paradigm, that is, a special, innovative set of views in the study of the philosophical, anthropological, cultural and socio-psychological theory of inter-ethnic communication.

The direction of studying of this theory can be defined as follows: [7,p. 95]

1) Examination of the sociocultural artifacts established by national ethnic communities (history, ideas, lifestyles, standard formation/education, evaluation criteria);

2) Building the desired different theoretical models for the organization, interpretations, explanations of national identity and characteristics characterizing a particular nationality in some multinational surroundings, in the midst of cultural and anthropological diversity and universals, in macro-and micro-dynamic cross-cultural processes [8,p. 70].

In accordance with this kind of positive objectives, the main subject areas of international communication are:

- historical, social, socio-ethnic, linguistic, regional, moral and psychological mechanisms for the generation and modification of nationally established facilities and technologies by nationalities that help them to regulate their domestic and international relations;

- mechanisms for the adjustment of specific complex of different international relations and relations at the individual, ethnic-national community levels;

- the nature and characteristics of the joint (friendly) life and activities of people at the level of "nation" and "society".

As a research site and the direction of international communication, the following have been established:

- regions of cultural and historical settlement of nationalities, modern Russia, various types of settlements;

- specialized areas of the national language, culture and psychology, the study of which has led to the creation of special subjects such as ethnology (ethnography), national (ethnic) psychology, ethnolinguistic anthropology, ethnoreligious anthropology, ethnopsychologic direction in the study of the art and culture of the peoples of modern Russia;

- analysis of the national and ethnic characteristics of the way of people's life (North Caucasians, the peoples of Volga region, the peoples of the North, etc.) [1, p.113].

The philosophical anthropological study of the subject matter of international communication cannot be meaningful without its specific aspect, such as the problem of intensity or the "formula of intensity coefficient" of the different international communication.The 
concept of "the formula of the inter-ethnic communication intensity coefficient" in the multinational region was first presented by the famous Soviet researcher of the theory and practice of national relations, problems of international education, Professor M.S. Dzhunusov [1,p. 151]. Borrowing the main ideas of this concept, transforming and changed them into the modern social and national conditions of Russia and the Republic of Dagestan, we will try to identify certain specific and principled positions that actually function in a particularly specific multinational subject of Russia, such as the Republic of Dagestan.

Imagine that the population of the city of Makhachkala consists of two nationalities of $P 1$ and $P 2$, and $P 1$ is 90 per cent of its population and $P 2$ is 10 per cent. If the sum of all the circles of international communication of each Makhachkala resident we assume as a unit and suppose that the representatives of these nationalities are relatively evenly accommodated in the labour collectives and place of residence, then the ratio of national and international communication of the nationality $\mathrm{P} 1$ will be $0.9: 0.1$, of nationality $\mathrm{P} 2=0.1: 0.9$. Under other equal conditions, the representatives of the first nationality have 9 times less possibilities to achieve intensive international communication than the second [1, p.159]. Under other equal conditions, representatives of small groups of nationalities of the Republic have possibilities to achieve more international and less within a nation communication. The situation is quite different for representatives of the larger population. Based on these communication principles of nationalities, we can present the formula of the interethnic communication circles intensity coefficient in the multinational region.We believe ${ }_{\text {that it looks like this: }} Q_{\text {иино }}=\left(1-\frac{\Pi_{1}}{100}\right) \cdot \frac{\Pi_{1}}{100}+\left(1-\frac{\Pi_{2}}{100}\right) \cdot \frac{\Pi_{2}}{100}+\left(1-\frac{\Pi_{3}}{100}\right) \cdot \frac{\Pi_{3}}{100}$, where P1 is the proportion of the first nationality as a percentage of the population of a given city. To calculate the intensity of the circle of international communication, it is necessary to:

1) To establish an index of the intensity of international communication for each nationality (percentage of this nationality in the population divided by one hundred per unit). For the first nationality $=1-0.9=0.1$; For the second one $=1-0.1=0.9$;

2) The index of the inter-ethnic communication circles intensity of each nationality to its share of the population (the share of P1 equals 0.9 , the share of P2 equals 0.1 ); 3 ) The data obtained for each nationality must be summed up $\left(1-\frac{\Pi_{1}}{100}\right) \cdot \frac{\Pi_{1}}{100}+\left(1-\frac{\Pi_{2}}{100}\right) \cdot \frac{\Pi_{2}}{100}$

In our example $(1-0.9) \times 0.9+(1-0.1) \times 0.1=0.18$. $Q_{\text {ино }}$-the coefficient of multiethnicity varies from one to zero (entirely the same national composition). In general terms, the formula can be expressed as follows, $Q_{\text {илно }}=\sum_{\mathrm{i}}\left(1-\frac{\Pi_{1}}{100}\right) \cdot \frac{\Pi_{1}}{100}$ where $\mathrm{i}$ is an order number of nationality, P-the specific weight of each nationality in the population.

Guided by this formula, we can derive the formula for the intensity coeddicient of the different circles of interethnic communication as a whole for Dagestan and specifically for cities, towns, regions and even for the nationalities of the republic. Typologizing cities, towns and districts of the Republic, we can conditionally say that the city of Makhachkala dominates and expresses the highest intensity in the direct communication of nationalities in the city, while Khasavyurt, Kaspiysk, Derbent, Kizilyurt, Kizlyar, etc. take the following positions, depending on the intensity of direct inter-ethnic communication.

The intensity of the different circles of inter-ethnic communication shows that this indicator depends primarily on the national composition of cities, workers' community and rural areas of the Republic. The data of the national composition, the percentage, and the proportion of their resettlement form the main and objective rate of this process[2, p. 7]. As we study the national composition of the city, town, district, collective, etc. through mathe- 
matical research, we can draw different variants of the intensity of direct and indirect communication between nationalities of the Republic of Dagestan. According to the intensity of the direct communication of nationalities, the Republic of Dagestan, in our view, may be conditionally divided into the following groups or zones:

1. The zone of highest intensity of direct, lively international communication among people of different nationalities (Makhachkala, Khasavyurt, Kaspiysk, Derbent, Kizlyar);

2. The medium intensity Zone of international communication (Kizilyurt, DagestanskiyeOgni, Yuzhno-Sukhokumsk, Kochubey, Buynaksk);

3. The zone of relatively low levels of international communication (Hasavjurtovsky, Novolaksky, Kayakentsky, Buynaksky, Kizlyarsky, Tarumovsky, Kizilyurtovsky, Karabudakhkentsky, Kumtorkalinsky, Rutulsky, Akushinsky, Nogaisky region);

4. The zone of the lowest level of nationalities communication, the zone of their actual absence.

The term "circles of international contacts", which we use quite often, can be defined as a system of genuine links and relationships among people of different nationalities, dependent on sustained, sufficiently large, long-term, kinship, neighboring, formal and informal, quantitative and qualitative factors. Guided by these principles (sustainability, frequency, regularity, generality, formality, informality, etc) specific typological circle variants of the international communication within Dagestan, we can speak of the apparent dominance, for example, of Lezghin-Tabasaran-Azerbaijan variants in the Derbent, and of AvarKumyk-Chechen-Laksky circle variants of international communication in Khasavyurt. Approximately in the same way, we must identify and substantiate the real existence of different circles of international communication when it is a question of cities of Makhachkala, Buinaksk, Buynaksk, Kizilyurt, Kizlyar, Izberbash, etc. Guided by this formula, we can deduce the formula of intensity coefficient of different circles of international contacts as a whole for Dagestan and specifically for cities, towns, districts and even for nationalities of the Republic.

The mathematical methods of researchare methods that have come to the sociology of international relations from economic science, demography and social statistics. The penetration of mathematics into the study of inter-ethnic relations is reflected in the growing use of mathematical methods in the preparation of studies, in processing of received empirical materials, in setting of objectives of sociological research, problems of interethnic communication, in the formation of hypotheses, in modeling and in the prediction of these relations. The use of mathematical methods in the sociology of inter-ethnic communication means that the general functions of this theory are explanations and previsions, and they obtain not only qualitative but also quantitative certainty[6; 11].

This zone comprises all regions of the Republic where the population is mainly the same national (Kulinsky, Botlihsky, Akhtinsky, Sulayman-Stalsky, Gumbetovsky, Uncukulsky regions, etc.) [5,p. 93]

To sum up, we can point out that the essential element in the system of objective factors that make and ensure the level, pace, frequency, intensity and positive location, the effectiveness of different circles of international communication, i.e., the establishment of interpersonal and international friendship, the growth of multinational labour collectives and inter-ethnic marriages, etc., is primarily a direct alive relationship of as many representatives of different nationalities as possible in the workplace, in their place of residence , education, formal and informal relationships on the healthy, friendly basis during the life of several generations. [4,p. 73] In the process of their productive and nonproductive activities, good-neighbourly and other relationships, as we have noticed, the coefficient of intensity of the international communication in the Republic of Dagestan, in its various cities, villages, regions, collectives, districts and so on, there are objectively different possibilities for the realization of this peculiar difficult process. That is, one or another part of the 
population of the Republic of Dagestan is not under the same conditions of entry into immediate, long-term, intensive, regular, everyday, formal and informal international contacts and relations in accordance with historical conditions. This objective factor in their resettlement primarily has the greatest impact in general on all the processes of international relations in the Republic, on their harmony, stabilization, balancing and regulation [9,p. 18]. These are mainly the sources of explanatory principles and models that can be used to interpret the diversity of national and cultural phenomena in identifying and learning the subject matter of the problems of international communication.

\section{Лumepamypa}

1. Джунусов М. С. Вопросы теории интернационального воспитания. Ташкент, 1980.

2. Жолобова И.К. Модификация традиционных символов в глобальной культуре // В сборнике: Наука сегодня: глобальные вызовы и механизмы развития / Материалы международной научно-практической конференции: в 2 частях. Вологда, 2017.

3. Ибрагимов Х.А. Социокультурные ценности современного дагестанского студенчества. Махачкала, 2011.

4. Мустафаев Ф.М. Межнациональное общение: социально-философский анализ. Махачкала, 2013.

5. СадохинА.П. Введение в теорию межкультурной коммуникации. М., 2005.

6. Соколов А.В. Общая теория социальной коммуникации. СПб., 2002.

7. Склярова Е.К., Камалова О.Н. Философские аспекты викторианского здравоохранения // Экономические и гуманитарные исследования регионов. 2015. №. 1.

8. Хоруженко К.М. Культурология. Энциклопедический словарь. Ростов н/Д., 1997.

9. Шарков Ф.И. Основы теории коммуникации. М., 2002.

10. Kolosova O.Y., Goncharov V.N. Spiritual life of society: regional aspect // НаучныйальманахстранПричерноморья. 2015. № 4. http://science-almanac.ru

11. Mustafayev F.M. Mustafayeva Z.S. The influence of customs and traditions on the formation and spiritual development of society in a multicultural region // НаучныйальманахстранПричерноморья. 2016. № 2. http://science-almanac.ru

\section{References}

1. Dzhunusov M.S. Issues of the theory of international training. Tashkent, 1980.

2. Zholobova I.K. Modification of traditional symbols in global culture // Science today: global challenges and mechanisms of development / Materials of international science-practical conference: in 2 parts. Vologda, 2017.

3. Ibragimov H.A. The socio-cultural values of modern students of Dagestan. Makhachkala, 2011.

4. Mustafayev F.M. International communication: Socio-philosophical analysis. Makhachkala, 2013.

5. Sadohin A.P. Introduction to the theory of cross-cultural communication. M., 2005.

6. Sklyarova E.K., Kamalova O.N. Philosophical aspects of Victorian health service // Economic and humanitarian researches of the regions. 2015. No 1.

7. Sokolov A.V. General theory of social communication. St. Petersburg, 2002.

8. Khoruzhenko K.M. Cultural science. Encyclopedic dictionary. Rostov-on-Don, 1997. 
9. Sharkov F.I. The bases of communication theory. M., 2002.

10. Kolosova O.Y., Goncharov V.N. Spiritual life of society: regional aspect // Science almanac of Black sea region countries. 2015. № 4. http://science-almanac.ru

11. Mustafayev F.M., Mustafayeva Z.S. The influence of customs and traditions on the formation and spiritual development of society in a multicultural region // Science almanac of Black sea region countries. 2016. No 2. http://science-almanac.ru 